NASA-TM-112484

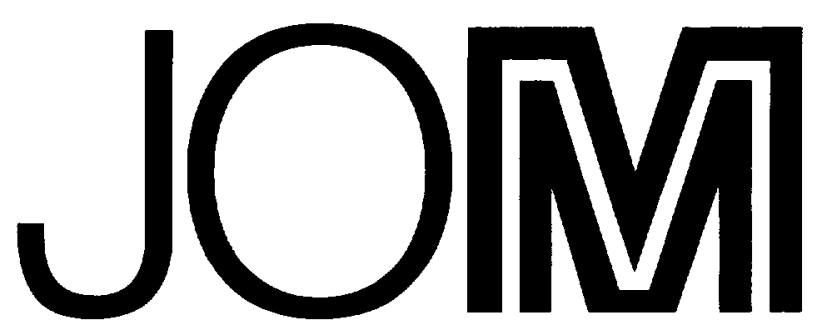

A publication of The Minerals, Metals \& Materials Society

\title{
The Oxidation and Protection of Gamma Titanium Aluminides
}

Michael P. Brady, William J. Brindley, James L. Smialek, and Ivan E. Locci 


\title{
The Oxidation and Protection of Gamma Titanium Aluminides
}

\author{
Michael P. Brady, William J. Brindley, James L. Smialek, and Ivan E. Locci
}

$\overline{\text { Authors' Note: }}$ All compositions are in atomic percent.

The excellent density-specific properties of the gamma class of titanium aluminides make them attractive for intermediate-temperature $\left(600-850^{\circ} \mathrm{C}\right)$ aerospace applications. The oxidation and embrittlement resistance of these alloys is superior to that of the $\alpha_{2}$ and orthorhombic classes of titanium aluminides. However, since gamma alloys form an intermixed $\mathrm{Al}_{2} \mathrm{O}_{3} / \mathrm{TiO}_{2}$ scale in air rather than the desired continuous $A l O$ scale, oxidation resistance is inadequate at the high end of this temperature range (i.e., greater than $750-800^{\circ} \mathrm{C}$ ). For applications at such temperatures, an oxidation-resistant coating will be needed; however, a major drawback of the oxidation-resistant coatings currently available is severe degradation in fatigue life by the coating. A new class of oxidation-resistant coatings based in the $T i$ Al-Cr system offers the potential for improved fatigue life.

\section{INTRODUCTION}

Titanium aluminides based on the $\gamma$ (TiAl) phase offer the potential for component weight savings of up to 50 percent over conventional superalloys in $600-850^{\circ} \mathrm{C}$ aerospace applications. ${ }^{1,2} \mathrm{Ex}$ tensive development efforts during the past ten years have led to the identification of engineering $\gamma$ alloys such as Ti$48 \mathrm{Al}-2 \mathrm{Cr}-2 \mathrm{Nb},{ }^{3}$ which offer a balance of room-temperature mechanical properties (1-4\% elongation, $10-20 \mathrm{MPa} \cdot \mathrm{m}^{1 / 2}$ fracture toughness) and high-temperature strength retention $(300-500 \mathrm{MPa}$ tensile strength at $\left.800^{\circ} \mathrm{C}\right) .^{1}$ These alloys are generally based on Ti-(45-48) Al and contain 3-15 volume percent $\alpha_{2}\left(\mathrm{Ti}_{3} \mathrm{Al}\right)$ as a second phase (Figure 1).1,2

The $\gamma$ class of titanium aluminides also offers oxidation and interstitial (oxygen, nitrogen) embrittlement resistance superior to that of the $\alpha_{2}$ and orthorhombic $\left(\mathrm{Ti}_{2} \mathrm{AlNb}\right)$ classes of titanium aluminides. However, environmental durability is still a concern, especially at temperatures above $750-800^{\circ} \mathrm{C}$ in air.

In this article, the fundamental aspects governing the oxidation behavior of gamma titanium aluminides are reviewed. The controversy regarding the Ti-Al-O phase diagram, the recently gained understanding of the detrimental role played by nitrogen during oxidation in air, and the oxidation and embrittlement behavior of engineering $\gamma$ alloys are discussed. The development of oxidation-resistant coatings for engineering $\gamma$ alloys is also reviewed, with a focus on the promising recent work in the Ti-Al-Cr system.

\section{FUNDAMENTALS OF GAMMA TITANIUM ALUMINIDE OXIDATION}

The goal during the oxidation of $\gamma$ titanium aluminides (and aluminides in general) is to form a continuous $\mathrm{Al}_{2} \mathrm{O}_{3}$ $(\alpha)$ scale. Alumina $\left(\mathrm{Al}_{2} \mathrm{O}_{3}\right)$ scales, by virtue of their extremely slow, parabolic rate of growth, are protective at temperatures in excess of $1,200^{\circ} \mathrm{C}$. Unfortunately, during the oxidation of $\gamma$ alloys in air, an intermixed $\mathrm{Al}_{2} \mathrm{O}_{3} / \mathrm{TiO}_{2}$ scale rather than a continuous $\mathrm{Al}_{2} \mathrm{O}_{3}$ scale is formed. ${ }^{5-10}$ Intermixed $\mathrm{Al}_{2} \mathrm{O}_{3} / \mathrm{TiO}_{2}$ scales are generally protective only to about $750-800^{\circ} \mathrm{C}$. They are less protective than continuous $\mathrm{Al}_{2} \mathrm{O}_{3}$ scales because $\mathrm{TiO}_{2}$ has a much higher rate of growth than $\mathrm{Al}_{2} \mathrm{O}_{3}$. Titania $\left(\mathrm{TiO}_{2}\right)$ may also act as a short-circuit transport path, resulting in interstitial oxygen/nitrogen dissolution into the alloy during elevated-temperature exposure in air. This can embrittle the alloy and degrade mechanical properties, in particular, fatigue life.

\section{Thermodynamics and the Ti-Al-O System}

A prerequisite for continuous $\mathrm{Al}_{2} \mathrm{O}_{3}$ scale formation during oxidation is that $\mathrm{Al}_{2} \mathrm{O}_{3}$ must be the most stable oxide on the alloy. However, the most stable oxide of titanium, usually $\mathrm{TiO}$ (depending upon temperature), is nearly as stable as $\mathrm{Al}_{2} \mathrm{O}_{3}$. The activity of aluminum in the Ti-Al system exhibits a large negative deviation from ideality. ${ }^{11-14}$ Therefore, the activities of aluminum and titanium in a given alloy determine whether $\mathrm{TiO}$

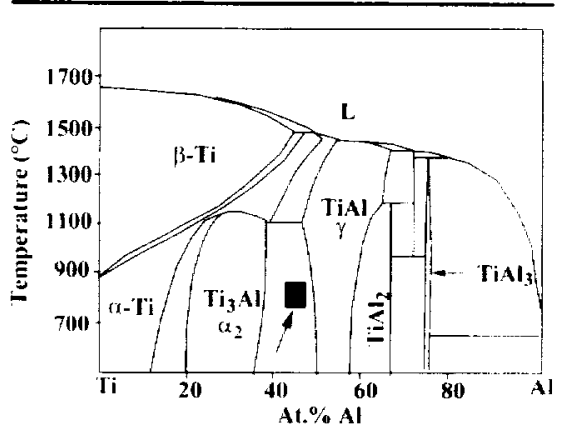

Figure 1. Binary Ti-Al phase diagram. ${ }^{4}$ or $\mathrm{Al}_{2} \mathrm{O}_{3}$ is the stable oxide for that particular composition. If $\mathrm{TiO}$ is more stable than $\mathrm{Al}_{2} \mathrm{O}_{3}$ a titanium-based oxide scale is formed. Such scales predominately contain $\mathrm{TiO}_{2}$ instead of $\mathrm{TiO}$ because of kinetic factors involved (discontinuous $\mathrm{Al}_{2} \mathrm{O}_{3}$ particles may also be present in the scale).

Thermodynamic calculations by Luthra $\left(800^{\circ} \mathrm{C}\right)^{15}$ and Rahmel etal. $\left(700^{\circ} \mathrm{C}\right.$, $900^{\circ} \mathrm{C}$, and $\left.1,100^{\circ} \mathrm{C}\right)^{1 \mathrm{th}}$ indicated that TiO was stable on binary $\mathrm{Ti}-\mathrm{Al}$ alloys containing less than about $50 \%$ aluminum (Figure 2). Thus, it was proposed that $\gamma$ alloys could not form a continuous $\mathrm{Al}_{2} \mathrm{O}_{3}$ scale because $\mathrm{Al}_{2} \mathrm{O}_{3}$ was not the most thermodynamically stable oxide on the alloy. However, recent experimental evidence shows that $\mathrm{Al}_{2} \mathrm{O}_{3}$ is more stable than $\mathrm{TiO}$ on $\mathrm{Ti}-\mathrm{Al}$ alloys containing as little as approximately 5-25\% aluminum (Figure 3). ${ }^{17-20}$

$\mathrm{Li}$ et al. ${ }^{17}$ and Becker et al. ${ }^{6}$ have explained the differences between the thermodynamically calculated $\mathrm{Ti}-\mathrm{Al}-\mathrm{O}$ phase diagram (Figure 2) and the experimentally determined $\mathrm{Ti}-\mathrm{Al}$-O phase diagram (Figure 3 ). They propose that oxygen solubility in the metal phases (in particular, $\alpha_{2}$ and $\gamma$ ), which was neglected in the thermodynamic calculations, plays a critical role in stabilizing $\mathrm{Al}_{2} \mathrm{O}_{3}$. Calculations by $\mathrm{Li}$ et al. ${ }^{17}$ suggest that when oxygen solubility in these phases is considered, a thermodynamically calculated $\mathrm{Ti}-\mathrm{Al}-\mathrm{O}$ phase diagram can match the experimentally determined $\mathrm{Ti}-\mathrm{Al}-\mathrm{O}$ phase diagram (Figure 3).

There has also been recent experimental evidence that one or more new ternary $\mathrm{Ti}_{x} \mathrm{Al}_{\gamma} \mathrm{O}_{z}$ phases, with an approximate composition of $\mathrm{Ti}-(25-35) \mathrm{Al}-(15-$ 20)O, may exist. ${ }^{21-25}$ The existence of such phase(s), with unknown thermodynamic properties, could also account for the discrepancies between the thermodynamically calculated and experimentally determined Ti-Al-O phase diagrams. ${ }^{23}$ While very recent data suggest that these $\mathrm{Ti}_{X} \mathrm{Al}_{Y} \mathrm{O}_{Z}$ phases may be metastable, ${ }^{26}$ the key point is that the experimental TiAl-O phase diagram studies clearly indicate that $\mathrm{Al}_{2} \mathrm{O}_{3}$ stability is not a barrier to $\gamma$ alloys oxidizing to establish a continuous $\mathrm{Al}_{2} \mathrm{O}_{3}$ scale.

\section{The Nitrogen Effect}

Binary $\gamma$ alloys form a continuous $\mathrm{Al}_{2} \mathrm{O}_{3}$ scale at temperatures up to $1,000^{\circ} \mathrm{C}$ in 
pure oxygen, but do not form a continuousalumina scale in air..$^{27}$ Approximately $60-70 \%$ aluminum is needed for binary $\mathrm{Ti}-\mathrm{Al}$ alloys to form a continuous $\mathrm{Al}_{2} \mathrm{O}_{3}$ scale in air, while only about $47-49 \%$ aluminum is needed in pure oxygen. ${ }^{5}$ The poor oxidation behavior of $\gamma$ alloys in air, as compared with pure oxygen, is commonly referred to as "the nitrogen effect." The nitrogen effect is significant because many of the engineering $\gamma$ alloys, like the binary $\gamma$ alloys, contain sufficient aluminum for continuous $\mathrm{Al}_{2} \mathrm{O}_{3}$ scale formation in oxygen but not in air.

The nitrogen effect has recently been the subject of intense, fundamental-oriented studies geared toward developing a mechanistic understanding of this phenomenon..$^{5.628-30}$ Dettenwanger and Rakowski et al. proposed that the inability of binary $\gamma$ alloys to establish a continuous $\mathrm{Al}_{2} \mathrm{O}_{3}$ scale from $800-900^{\circ} \mathrm{C}$ in air is related to the formation of $\mathrm{TiN}$ during the initial stages of oxidation. ${ }^{28,29}$ Cross-section transmission electron mi-

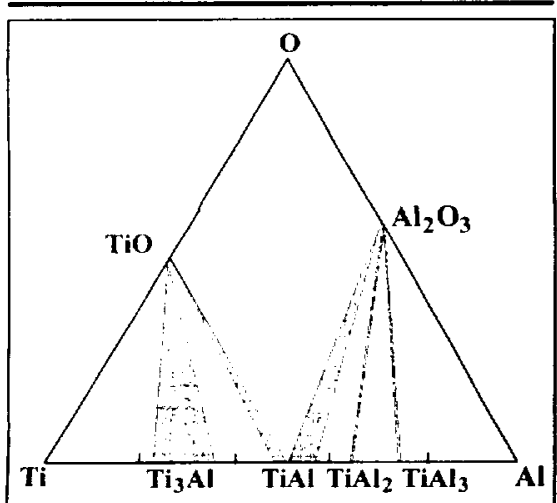

Figure 2. A schematic partial Ti-Al-O phase diagram obtained from thermodynamic calculations (based on Luthra ${ }^{15}$ and Rahmel et al. ${ }^{16}$ ). The two-phase fields with $\mathrm{TiO}$ and $\mathrm{Al}_{2} \mathrm{O}_{3}$ are highlighted in gray and show $\gamma$ in equilibrium with both $\mathrm{Al}_{2} \mathrm{O}_{3}$ and TiO.

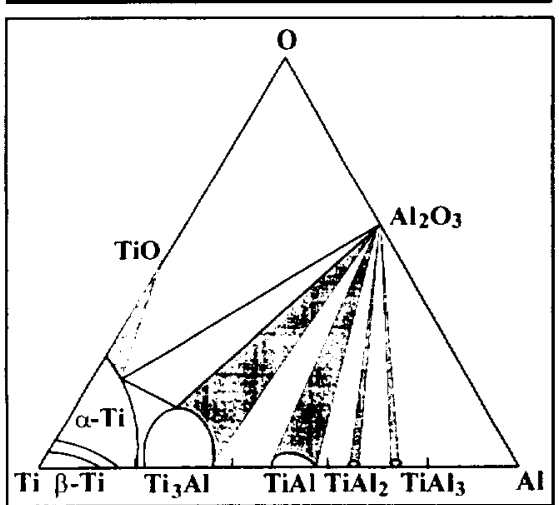

Figure 3. A schematic partial Ti-Al-O phase diagram obtained from experimental studies (based on References 17-20). The two-phase fields with $\mathrm{TiO}$ and $\mathrm{Al}_{2} \mathrm{O}$ are highlighted in gray and show that both $\gamma$ and $\alpha_{2}$ are in equilibrium with $\mathrm{Al}_{2} \mathrm{O}_{3}$. Note that although the cited studies agree that $\mathrm{Al}_{2} \mathrm{O}_{3}$ is the stable oxide for Ti- $(<<50) A l$, the details of the $\mathrm{Al}_{2} \mathrm{O}_{3}$ l $\mathrm{TiO}$ stability changeover vary somewhat from study to study croscopy (TEM) analysis of the scale formed on Ti-50Al after one hour at $900^{\circ} \mathrm{C}$ in air revealed an alternating sequence of TiN and $\mathrm{Al}_{2} \mathrm{O}_{3}$ at the metal/scale interface ${ }^{28,29}$ The presence of TiN in this layer was postulated to interrupt the establishment of a continuous $\mathrm{Al}_{2} \mathrm{O}_{3}$ scale (Figure 4).28.29 As oxidation proceeds, the TiN is subsequently oxidized to form $\mathrm{TiO}_{2}{ }^{29}$ This process results in the formation of an intermixed $\mathrm{Al}_{2} \mathrm{O}_{3} / \mathrm{TiO}_{2}$ scale rather than a continuous $\mathrm{Al}_{2} \mathrm{O}_{3}$ scale (Figure 4). ${ }^{29}$

Although further experimental confirmation is needed, the Dettenwanger and Rakowski et al. mechanism provides a very plausible explanation for the nitrogen effect. Regardless of the exact mechanistic details, the nitrogen effect appears to be the main barrier to continuous $\mathrm{Al}_{2} \mathrm{O}_{3}$ scale formation by $\gamma$ alloys in air.

\section{Oxidation and Embrittlement of Engineering $\gamma$ Titanium Aluminides}

Ternary and higher order alloying additions can reduce the rate of oxidation of $\gamma$ alloys. $6,7,9,10,27,31-39$ Of particular benefit are small $(1-4 \%)$ ternary additions of tungsten, niobium, and tantalum. ${ }^{9,27,33-37,39}$ When combined with quaternary additions of $1-2 \%$ chromium or manganese, further improvement in oxidation resistance is gained. ${ }^{34,37}$ However, it is important to stress that these small alloying additions do not result in continuous $\mathrm{Al}_{2} \mathrm{O}_{3}$ scale formation. Rather, a complex intermixed $\mathrm{Al}_{2} \mathrm{O}_{3}$ / $\mathrm{TiO}_{2}$ scale is still formed, but the rate of growth of this scale is reduced.

The mechanisms by which these small alloying additions slow the rate of oxidation of $\gamma$ alloys are not well understood. ${ }^{10}$ Proposed explanations include the reduced growth rate of $\mathrm{TiO}_{2}$ by doping, ${ }^{27}$ an increase in $\mathrm{Al} / \mathrm{Ti}$ activity ratio to favor $\mathrm{Al}_{2} \mathrm{O}_{3}$ scale formation, $, 27,34$ and a reduction in alloy oxygen solubility to prevent internal oxidation. ${ }^{939}$ However, further experimental examination of the influence of these mechanisms on the oxidation behavior of $\gamma$ alloys is needed, particularly in the $600-850^{\circ} \mathrm{C}$ application temperature range.

Based on the following data and the data available in the literature, ${ }^{32,37,38,40,41}$ engineering $\gamma$ alloys exhibit acceptable oxidation rates up to about $750-800^{\circ} \mathrm{C}$ in air. Figure $5^{41}$ shows oxidation data for several engineering $\gamma$ alloys of current interest: Ti-48Al-2Cr-2Nb, Ti-46.5Al$3 \mathrm{Nb}-2 \mathrm{Cr}-0.2 \mathrm{~W}(\mathrm{~K}-5){ }^{42}$ and $\mathrm{Ti}-46 \mathrm{Al}-5 \mathrm{Nb}-$ $1 \mathrm{~W}(\text { Alloy } 7)^{43}$ at $800^{\circ} \mathrm{C}$ in air. At regular intervals, the samples were removed from the test furnace at temperature, aircooled, weighed, and returned to the test furnace at temperature (i.e., interrupted weight-gain test). Therefore, interrupted weight-gain exposures involve both an isothermal and cyclic temperature component.

\section{$\mathrm{Al}_{2} \mathrm{O}_{3} \mathrm{TiN} \mathrm{Al}_{2} \mathrm{O}_{3} \mathrm{TiN} \mathrm{Al}_{2} \mathrm{O}_{3}$}

$1 \mathrm{~h}$ in Air

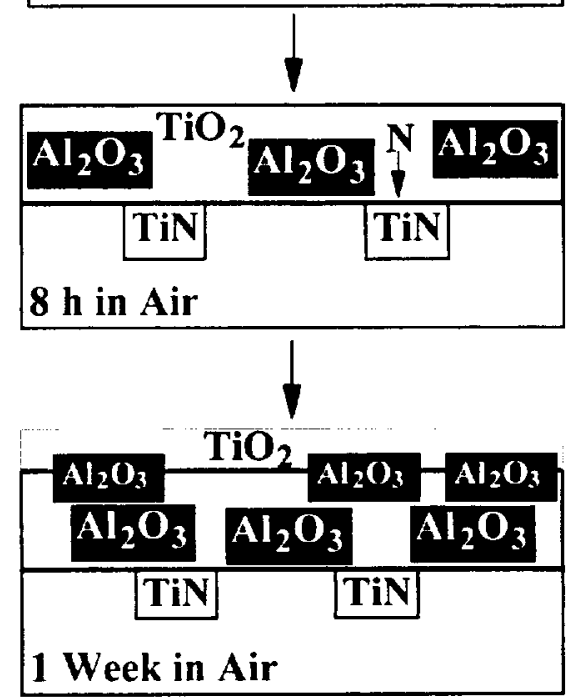

Figure 4. Portions of the Rakowski et al. schematic mechanism of the nitrogen effect for binary $\gamma$ alloys at $800-900^{\circ} \mathrm{C}$ in air (a description is provided only for the external scale). ${ }^{29}$

The Ti-48Al-2Cr-2Nb alloy samples oxidized at a relatively rapid rate, with one of the two samples suffering from significant scale spallation (weight loss) after about 500 hours at $800^{\circ} \mathrm{C}$ in air (Figure 5). The K-5 and Alloy $7 \gamma$ alloys exhibited low rates of oxidation up to 1,000 hours at $800^{\circ} \mathrm{C}$ in air. The superior oxidation resistance of K-5 and Alloy 7 is attributable to the presence of tungsten and a higher level of niobium in these alloys. However, the oxidation kinetics for K-5 and Alloy 7 were strongly linear in character beyond 500 hours, which suggests a possible degradation in the protectiveness of the scale.

The scale formed on Ti- $48 \mathrm{Al}-2 \mathrm{Cr}-2 \mathrm{Nb}$ after 9,000 hours of isothermal oxidation at $704^{\circ} \mathrm{C}$ in air is shown in Figure 6 (after Locci et al.)..$^{40}$ Despite the very long-term exposure, the scale is only about $15 \mu \mathrm{m}$ thick, an acceptable rate of oxidation for many applications. From the gas/scale interface inward, the microstructure consisted of $\mathrm{TiO}_{2} / \mathrm{Al}_{2} \mathrm{O}_{3}$-rich (not continuous)/intermixed $\mathrm{Al}_{2} \mathrm{O}_{3}+\mathrm{TiO}_{2} / \mathrm{TiN} /$ $\mathrm{TiAl}_{2} /$ bulk alloy. (The identification of TiN and $\mathrm{TiAl}_{2}$ were based solely on composition data obtained by wavelength dispersive analysis.)

The outer-scale microstructure formed on Ti-48Al-2Cr-2Nb after 9,000 hours at $704^{\circ} \mathrm{C}$ in air (Figure 6) is qualitatively similar to that reported for binary $\gamma$ alloys after short-term, high-temperature exposures (less than 1,000 hours at 900 $1,000^{\circ} \mathrm{C}$ ) in air. ${ }^{5,6,10}$ (Little information is available on the scales formed on binary $\gamma$ alloys after long-term, low-temperature exposures such as is available for $\mathrm{Ti}$ - 


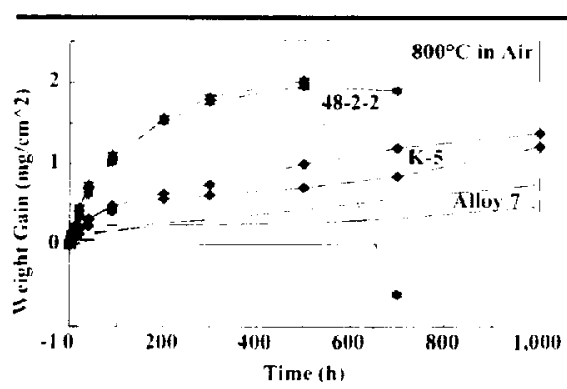

Figure 5. Interrupted weight gain oxidation data for Ti-48Al-2Cr-2Nb (48-2-2), Ti-46.5Al$3 \mathrm{Nb}-2 \mathrm{Cr}-0.2 \mathrm{~W}$ (K-5), and Ti-46Al-5Nb-1W (Alloy 7 ) at $800^{\circ} \mathrm{C}$ in air. ${ }^{4 t}$

$48 \mathrm{Al}-2 \mathrm{Cr}-2 \mathrm{Nb}$.) However, the inner-scale microstructure is markedly different. In binary $\gamma$ alloys, discrete TiN particles ${ }^{28,24}$ as well as an embrittled zone of aluminum-depleted, oxygen-rich metal phase $(s)^{21,25,44}$ are formed at the metal/ scale interface. In Ti-48Al-2Cr-2Nb, a continuous layer of TiN is formed at the metal/scale interface (Figure 6). ${ }^{40}$ The depletion of titanium to form the TiN layer effectively enriches the alloy in aluminum, which then results in the formation of $\mathrm{TiAl}_{2}$ just below the TiN layer (Figure 6).

The formation of this $\mathrm{TiAl}_{2}$ layer is postulated to be beneficial from an environmental durability viewpoint. First, as oxidation proceeds, the $\mathrm{TiAl}_{2}$ layer would primarily be oxidized to form $\mathrm{Al}_{2} \mathrm{O}_{3}$. Second, because of its high aluminum content, $\mathrm{TiAl}_{2}$ is expected to have a low permeability to oxygen and nitrogen. Therefore, the TiAl, layer would aid in resisting interstitial oxygen/nitrogen penetration and embrittlement. A possible concern, however, is a degradation in mechanical properties, especially fatigue life, because the $\mathrm{TiN}$ and $\mathrm{TiAl}_{2}$ phases are themselves extremely brittle.

The scale formed by $\mathrm{Ti}-48 \mathrm{Al}-2 \mathrm{Cr}-2 \mathrm{Nb}$ provides adequate oxidation resistance up to $750-800^{\circ} \mathrm{C}$ in air. However, it is not clear if it is a sufficient barrier to interstitial oxygen/nitrogen penetration into the alloy. Significant penetration of oxygen or nitrogen could lead to interstitial embrittlement, as is observed in the $\alpha_{2}$ and orthorhombic titanium aluminides, ${ }^{36,45,46}$ and a subsequent degradation of mechanical properties.

Electron microprobe analysis of the Ti-48Al-2Cr-2 $\mathrm{Nb}$ sample oxidized for 9,000 hours at $704^{\circ} \mathrm{C}$ in air showed no evidence of oxygen/nitrogen penetration into the alloy ahead of the metal/ scale interface. ${ }^{40}$ Cross-section microhardness evaluation of $\mathrm{Ti}-48 \mathrm{Al}-2 \mathrm{Cr}-2 \mathrm{Nb}$ oxidized for 700 hours at $800^{\circ} \mathrm{C}$ in air (Figure 7) also showed little evidence of interstitial hardening ahead of the metal/ scale interface. ${ }^{41}$ Similar results were obtained for K-5 and Alloy 7.41 By comparison, the orthorhombic-based alloy Ti-22Al-20Nb-2Ta-1Mo, which is more oxidation resistant than $\mathrm{Ti}-48 \mathrm{Al}-2 \mathrm{Cr}-2 \mathrm{Nb}$ at $800^{\circ} \mathrm{C}$ in air (Figure 8), suffers from extensive interstitial embrittlement ahead of the metal/scale interface (Figure 7). ${ }^{47}$ This suggests that the oxidation rate of titanium aluminides does not necessarily correlate with susceptibility to interstitial embrittlement ${ }^{47}$ and that engineering $\gamma$ alloys exhibit superior resistance to interstitial penetration as compared to $\alpha_{2}$ and orthorhombic alloys ${ }^{41,47}$

However, electron microprobe and microhardness evaluations are only sensitive to interstitial penetration beyond about $5 \mu \mathrm{m}$ from the metal/scale interface. Fatigue studies, which are more sensitive to environmental embrittlement, do suggest a possible embrittlement problem for engineering $\gamma$ alloys. An order-of-magnitude higher fatigue crack growth rate was observed in air, as compared with vacuum, for alloy $\mathrm{K}-5$ and $\mathrm{Ti}-47 \mathrm{Al}-1.5 \mathrm{Cr}-2 \mathrm{Nb} .{ }^{48,49}$ The worstcase condition for crack growth resistance was found to occur around $600^{\circ} \mathrm{C} .4$ It is not clear whether the higher fatigue crack growth rates observed in air were associated with very near-surface interstitial oxygen/nitrogen embrittlement, TiN/TiAl ${ }_{2}$ formation, or some other mechanism. These data suggest that an oxidation-resistant coating may be beneficial for engineering $\gamma$ alloys for application temperatures below $750-800^{\circ} \mathrm{C}$ to protect from environmental embrittlement. At temperatures above $750-800^{\circ} \mathrm{C}$, oxidation rates are unacceptably high for many long-term applications, and an oxidation-resistant coating will likely be required.

\section{OXIDATION-RESISTANT COATINGS FOR GAMMA TITANIUM ALUMINIDES}

The development of oxidation-resistant coatings for titanium aluminides was recently reviewed by Taniguchi ${ }^{5 n}$ and Streiff. ${ }^{51}$ Three general coating alloy approaches have been taken for protecting titanium aluminides: $\mathrm{MCr}$ AlY ( $\mathrm{M}=$ $\mathrm{Ni}, \mathrm{Fe}, \mathrm{Co}),{ }^{52-56}$ aluminizing, ${ }^{57.63}$ and silicides/ceramics. ${ }^{63-66}$ Protection of titanium aluminides under oxidizing con-

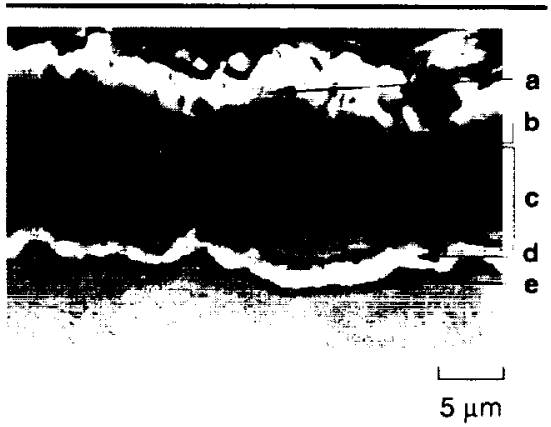

Figure 6. A scanning electron microscopy backscatter-mode micrograph of Ti-48Al-2 $\mathrm{Cr}$ $2 \mathrm{Nb}$ after 9,000 hours at $704^{\circ} \mathrm{C}$ in air.$^{40}$ Note that the identification of $\mathrm{TiN}$ and $\mathrm{TiAl}_{2}$ at the metal/scale interface was based solely on microprobe composition analysis: (a) $\mathrm{TiO}_{2}$ (light), (b) $\mathrm{Al}_{2} \mathrm{O}_{3}$-rich (dark), (c) intermixed $\mathrm{Al}_{2} \mathrm{O}_{3}+\mathrm{TiO}_{2}$, (d) TiN, and (e) TiAl .

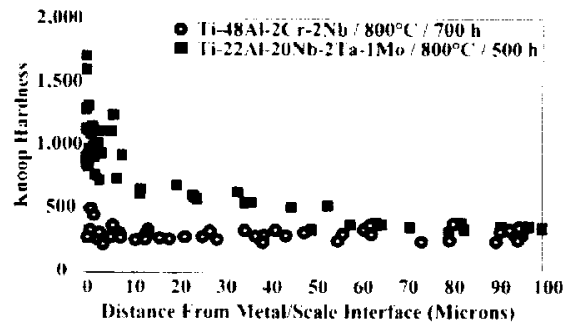

Figure 7. Knoop microhardness data (at $25 \mathrm{~g} /$ $15 \mathrm{~s}$ ) as a function of distance from the metal/ scale interface for $\mathrm{Ti}-48 \mathrm{Al}-2 \mathrm{C} r-2 \mathrm{Nb}$ and $\mathrm{Ti}$ 22Al-20Nb-2Ta- 1 Mo after 700 hours and 500 hours exposures, respectively, at $800^{\circ} \mathrm{C}$ in air. 41,47

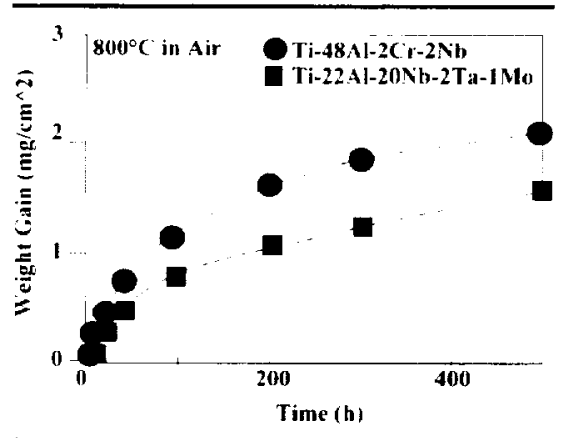

Figure 8. Interrupted weight gain oxidation data for Ti-48Al-2Cr-2Nb and Ti-22Al-20Nb$2 \mathrm{Ta}-1 \mathrm{Mo}$ at $800^{\circ} \mathrm{C}$ in air. ${ }^{41,47}$

ditions has been achieved with all three approaches, however, studies of such coatings on $\alpha_{2}$-and or thorhombic-based titanium aluminides (monolithic and composite) report severe lifetime degradation under fatigue conditions. ${ }^{65,67}$ The fatigue life of coated material is often reduced to below that of uncoated material. ${ }^{65,67}$ Similar results are also expected for such coatings that are on $\gamma$ titanium aluminides.

The degradation in the fatigue life of titanium aluminides by coatings results from three main factors: the formation of brittle coating-substrate reaction zones (chemical incompatibility), the brittleness of the coating alloy, and the differences in the coefficient of thermal expansion between the coating and the substrate (CTE mismatch). MCrAlY coatings, which are successfully used to protect nickel-, iron-, and cobalt-based superalloys, are not chemically compatible with titanium aluminides ${ }^{54,56}$ and form brittle coating/substrate reaction zones at $800^{\circ} \mathrm{C} .^{54,67}$ Aluminizing treatments result in the surface formation of the $\mathrm{TiAl}_{3}$ and $\mathrm{TiAl}_{2}$ phases, which are brittle and exhibit CTE mismatches with $\alpha$, orthorhombic, and $\gamma$ titanium aluminides. ${ }^{61} \mathrm{Si}$ licide and ceramic coatings are also generally too brittle to survive fatigue conditions. ${ }^{65,67}$

It should be noted that most work to date on the fatigue behavior of coated titaniumaluminides has been performed under low-cycle fatigue (LCF) conditions, primarily on $\alpha_{2}$ - and orthorhombic-based titanium aluminides. The initial commercial introduction of $\gamma$ tita- 
nium aluminides will likely involve very low load, stiffness-limited applications where less severe high-cycle fatigue (HCF) conditions dominate. Under such conditions, coating alloy property requirements are not as stringent, and it is possible that some of the aforementioned coating approaches may be successful in these cases.

\section{Ti-Al-Cr Oxidation-Resistant Coating Alloys}

The ideal oxidation-resistant coating for $\gamma$ alloys would be Ti-Al based for optimal chemical and mechanical compatibility with $\gamma$ substrates, be capable of forming a continuous $\mathrm{Al}_{2} \mathrm{O}_{3}$ scale to protect from both oxidation and interstitial oxygen/nitrogen embrittlement, and possess reasonable mechanical properties to survive HCF. No ideal combination of these properties exists at present. However, reasonable compromises have been achieved with coating alloys based in the Ti-Al-Cr system.

Perkins and Meier et al. ${ }^{68}$ discovered that $\mathrm{Ti}-\mathrm{Al}-\mathrm{Cr}$ alloys containing a minimum of $8-10 \%$ chromium are continuous $\mathrm{Al}_{2} \mathrm{O}_{3}$ scale formers from $800-1,300^{\circ} \mathrm{C}$ in air (Figure 9). In a cooperative effort between the University of Pittsburgh (Pitt), Lockheed Missiles and Space Company (LMSC), and General Electric Aircraft Engines (GEAE), the $\mathrm{Al}_{2} \mathrm{O}_{3}$-forming $\mathrm{Ti}-\mathrm{Al}-\mathrm{Cr}$ alloys were investigated as oxidation-resistant coating alloys for $\gamma$ titanium aluminides. ${ }^{69,70}$ This program met with considerable success. A sputtered $\mathrm{Ti}-44 \mathrm{Al}-28 \mathrm{Cr}$ coating successfully

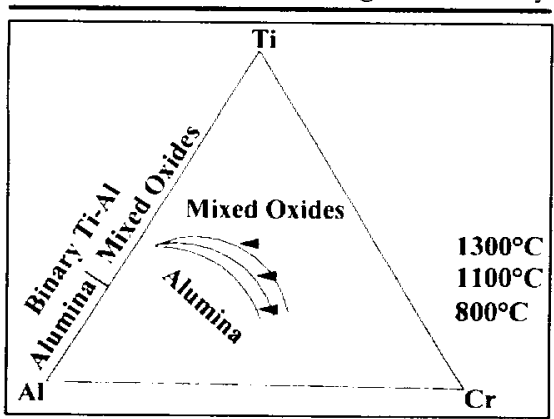

Figure 9. Schematic $\mathrm{Ti}-\mathrm{Al}-\mathrm{Cr}$ oxide map of Perkins and Meier et al. ${ }^{68}$

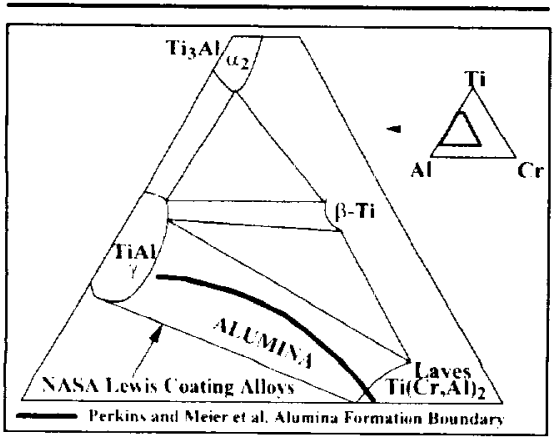

Figure 10. Schematic partial $800-1,000^{\circ} \mathrm{C}$ TiAl-Cr phase diagram, ${ }^{75}$ based on References 71-75and 79 , showing the composition range of the $\gamma+$ Laves NASA Lewis oxidation-resistant coating alloys. ${ }^{78}$
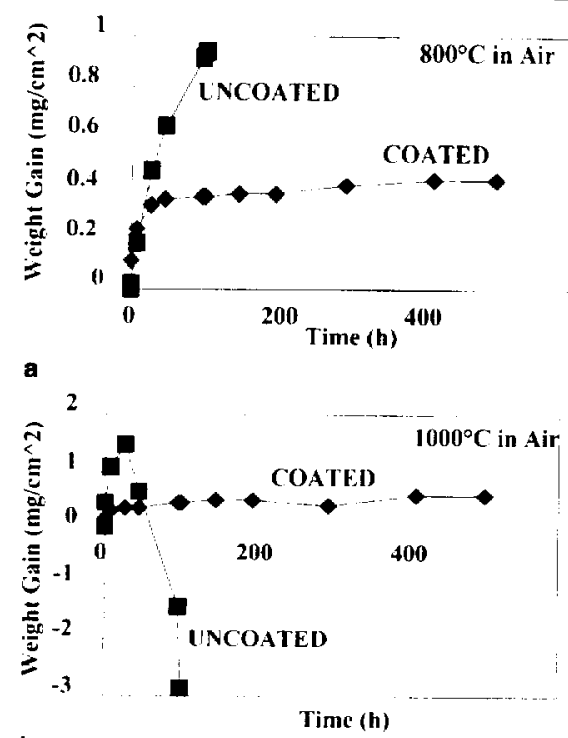

b

Figure 11. Interrupted weight-gain oxidation data for LPPS Ti-51Al-12Cr-coated and uncoated Ti-48Al-2Cr-2Nb at (a) $800^{\circ} \mathrm{C}$ and (b) $1,000^{\circ} \mathrm{C}$ in air.

protected $\mathrm{Ti}-47 \mathrm{Al}-2 \mathrm{Cr}-2 \mathrm{Ta}$ under longterm $(2,000$ hours $)$ cyclic oxidation at $900^{\circ} \mathrm{C}$ in air. ${ }^{70} \mathrm{Coating}$ composition optimization studies identified $\mathrm{Ti}-50 \mathrm{Al}-20 \mathrm{Cr}$ as holding the most promise as an oxidation-resistant coating for $\gamma$ alloys. ${ }^{69} \mathrm{How}$ ever, the $\mathrm{Ti}-\mathrm{Al}-\mathrm{Cr}$ alloys examined under this program were brittle and exhibited some minor chemical incompatibility problems (e.g., small reaction zone of chromium-rich precipitates) with yalloy substrates. ${ }^{69}$ Difficulties in depositing high-quality coatings by plasma spray methods were also encountered.69

A second generation of Ti-Al-Cr coating alloys based on the Pitt/LMSC/ GEAE work was recently developed at the NASA Lewis Research Center. The goal of this program was to co-optimize the oxidation resistance, mechanical properties, and $\gamma$ alloy compatibility of Ti-Al-Cr coating alloys. To accomplish this, the critical phase equilibria in the $\mathrm{Al}_{2} \mathrm{O}_{3}$-forming composition range were determined, ${ }^{71}$ and a microstructure/ property approach was adopted..$^{72}$

The $\mathrm{Al}_{2} \mathrm{O}_{3}$-forming $\mathrm{Ti}$-Al-Cr composition range was found to be multiphase and consisted primarily of the $\tau\left(\mathrm{Ll}_{2}\right.$ phase centered on Ti-67Al-8Cr) or $\gamma$ phases and the $\mathrm{Ti}(\mathrm{Cr}, \mathrm{Al})_{2}$ (Laves $^{73,74}$ ) phase. $^{7}$ The key to oxidation resistance was the Laves phase, which was capable of continuous $\mathrm{Al}_{2} \mathrm{O}_{3}$ scale formation despite an aluminum content of only 37$42 \% .^{72,75}$ Unfortunately, the Laves phase was also a major source of alloy brittleness. ${ }^{72}$

Work by Klansky et al. on Ti-Al-Cr alloys hot isostatically pressed at $1,200^{\circ} \mathrm{C}$ showed that mixing the Laves phase with the $\tau$ phase or the $\gamma$ phase improved cracking resistance (i.e., reduced alloy brittleness) as measured by room-temperature microhardness indentation. ${ }^{73}$
Their results suggest that basing a $\mathrm{Ti}-\mathrm{Al}$ $\mathrm{Cr}$ coating alloy on either the $\tau$ phase or the $\gamma$ phase would reduce alloy brittleness; however, the $\tau$ phase in this composition range decomposes to the brittle $\mathrm{TiAl}_{2}$ phase and a chromium-rich phase $\left(\mathrm{Cr}_{2} \mathrm{~A}\right)^{71}$ or, more likely, $\left.\beta-\mathrm{Cr}^{76}\right)$ on exposure at $800^{\circ} \mathrm{C}$. Thus, any beneficial effects of the $\tau$ phase on cracking resistance are lost after exposure in the temperature range whereapplication of these coating alloys is expected. ${ }^{71}$

In contrast, the $\gamma$ phase in the $\mathrm{Al}_{2} \mathrm{O}_{3}$ forming $\mathrm{Ti}-\mathrm{Al}-\mathrm{Cr}$ alloys is stable from room temperature to at least $1,000^{\circ} \mathrm{C}, 7^{1,72}$ Additionally, the $\gamma$ phase is capable of some limited room-temperature ductility. ${ }^{\pi}$ Therefore, the best current option for reducing $\mathrm{Ti}-\mathrm{Al}-\mathrm{Cr}$ coating alloy brittleness is to base the alloy on the $\gamma$ phase. ${ }^{71,72}$ Most of the Pitt/LMSC/GEAE coating alloys were based on the Laves phase (Ti-44Al-28Cr) or the $\tau$ phase (Ti50Al-20Cr).

A region of $\mathrm{Al}_{2} \mathrm{O}_{3}$-forming $\gamma+$ Laves $\mathrm{Ti}-\mathrm{Al}-\mathrm{Cr}$ coating alloys was identified by Brady et al. ${ }^{78}$ in which the $\gamma$ phase was continuous in the microstructure (Figure 10). This further reduces brittleness because the brittle Laves phase is surrounded by the $\gamma$ phase in the microstructure. Compatibility with $\gamma$ alloys is also optimized because these $\mathrm{Ti}-\mathrm{Al}-\mathrm{Cr}$ coating alloys consist predominately of the $\gamma$ phase.

A representative $\gamma+$ Laves coating alloy, $\mathrm{Ti}-51 \mathrm{Al}-12 \mathrm{Cr}{ }^{78}$ was applied to $\mathrm{Ti}-$ $48 \mathrm{Al}-2 \mathrm{Cr}-2 \mathrm{Nb}$ by low-pressure plasma spray (LPPS). Interrupted weight-gain oxidation tests at $800^{\circ} \mathrm{C}$ and $1,000^{\circ} \mathrm{C}$ in air indicated that the coating successfully protected the substrate from oxidation (Figure 11). A typical coating/substrate region after 100 hours at $1,000^{\circ} \mathrm{C}$ in air is shown in Figure 12. The absence of cracks in the coating and the absence of a significant interdiffusion zone with the substrate demonstrate the excellent chemical and thermal compatibility of the $\mathrm{Ti}-51 \mathrm{Al}-12 \mathrm{Cr}$ coating with the $\mathrm{Ti}$ $48 \mathrm{Al}-2 \mathrm{Cr}-2 \mathrm{Nb}$ substrate.

A high-magnification micrograph of
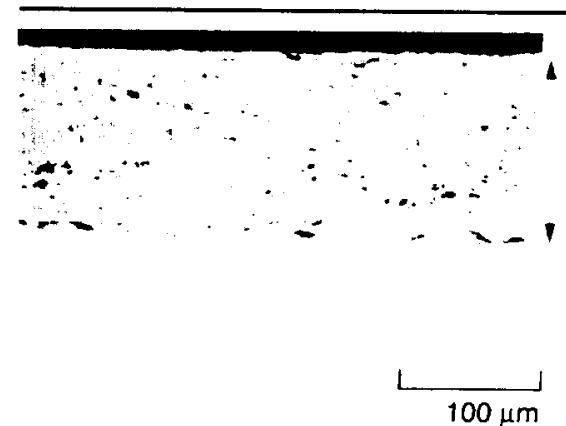

Figure 12. A scanning electron microscopy backscatter-mode micrograph of LPPS Ti51 Al-12Cr-coated Ti-48AL-2Cr-2Nb after 100 hours of interrupted weight gain exposure at $1,000^{\circ} \mathrm{C}$ in air. The coating area is indicated by the range marker. The black areas in the coating are porosity. 


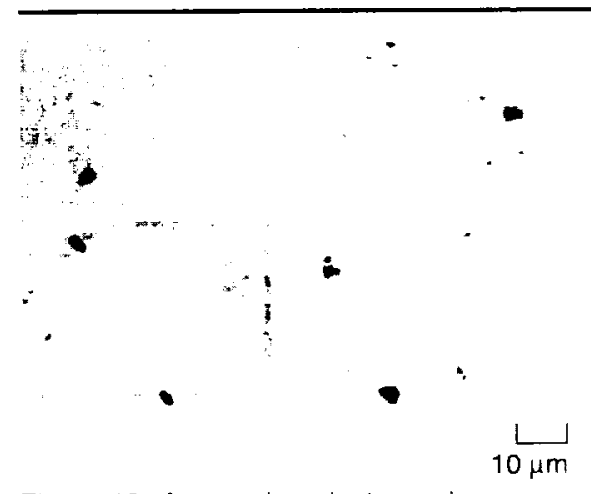

Figure 13. A scanning electron microscopy backscatter-mode micrograph of an LPPS Ti$51 \mathrm{Al}-12 \mathrm{Cr}$ coating after 500 hours of interrupted weight-gain exposure at $1,000^{\circ} \mathrm{C}$ in air. The microstructure consists of the $\gamma$ phase (dark) and the Laves phase (light). The black regions are porosity. The Vicker's microhardness indentation was performed at $1 \mathrm{~kg}$ for 15 seconds.

the LPPS Ti-51 Al-12Cr coating after exposure at $1,000^{\circ} \mathrm{C}$ for 500 hours is shown in Figure 13. In general, the Laves phase regions in the microstructure are surrounded by the $\gamma$ phase. The crack resistance imparted to the coating alloy by the continuous $\gamma$ phase microstructure was evaluated via microhardness indent evaluation. Under $1 \mathrm{~kg} / 15 \mathrm{~s}$ indentation conditions, only small isolated cracks $1-3 \mu \mathrm{m}$ in length were observed (Figure 13). The cracks were confined to the Laves phase and were blunted at the Laves $/ \gamma$ interface. At lower loads, no cracking was observed. In contrast, Laves-based alloys suffer from extensivecracking after microhardness indentation at loads of only $100 \mathrm{~g} .{ }^{72}$ Evaluation of the LCF and HCF behavior of LPPS $\mathrm{Ti}-51 \mathrm{Al}-12 \mathrm{Cr}$-coated $\mathrm{Ti}-48 \mathrm{Al}-2 \mathrm{Cr}-2 \mathrm{Nb}$ is in progress.

\section{CONCLUSION}

In terms of environmental durability (oxidation and interstitial embrittlement), the $\gamma$ class of titanium aluminides looks promising for applications below $750-800^{\circ} \mathrm{C}$ in air. Future work should emphasize the interaction between environmental effects and mechanical properties, fatigue, in particular. For applications above $750-800^{\circ} \mathrm{C}$, an oxidation-resistant coating will likely be necessary for $\gamma$ alloys. Future coating alloy development should include an evaluation of the effects of the coating on fatigue life.

\section{ACKNOWLEDGEMENTS}

The authors thank Sushil Jain of Allison Engine Company, Jon Schaeffer of GEAE, and Young-Won Kim of Universal Energy Systems for providing gamma material for study and for their helpful discussions. The authors also thank J. Nesbitt, J. Doychak, F. Dettenwanger, and B. Gleeson for their helpful discussions. M.P. Brady acknowledges the financial support of a National Research Council post-doctoral fellowship. The NASA
Lewis Ti-Al-Cr coating alloy development program was funded under the Advanced High Temperature Engine Materials Technology Program (HITEMP).

\section{References}

1 Y.W. Kim and F.H Froes, High Temperature Aluminides and Intermetallics, ed. S.H. Whang et al. (Warrendaie, I'A. TMS 1990), p. 465

2. M. Yamaguchi, Titanium' '92, ed. F.H. Froes and I Caplan (Warrendale, PA: TMS, 1993), p. 959

(Warrendale, PA: TMS, 1993), P. 959 . Huang L.S. patent 4,879,092 (1989)

C.C. Huang. S. patent 4,879,092 (1989). 1. C.R. Kattiner, J.

(1992), 2081 . inc.ed. T. Grobstein and I. Doychak (Warendale, PA TMS, inced T. Grob

1488), p. 185

6. 5 . Becker et al , Ox. Met, $38(5 / 6)$ (1992), p. 425

7. K. Maki et al, Mal. Sci. and Eng., A153 (1992), p 391

8. S.A. Kekare. D.K. Shelton, and P. B. Aswath, Mat. Re's So Sump. Proc., vol 288 (Pittsburgh, PA: MRS, 1943i, F. 1025 9 Y. Shida and H. Anada, Mat. Trans., IIM, 35 (9) (1494), P 62.3

10. A. Rahmel, W.j. Quadakkers, and M. Schutze, Materiuls and Corrosion, 46 (1995), p. 281

11. V.V. Samokhval, P. A. Poleshuk, and A.A. Vecher, Raw ! Phiss. Chem., 45 (8) (1971). p. 1174

12. M. Hoch and R. Usell, Jr., Met Trans, 2 (1971), F 2627 . 13. N.S Jacobson, M.P. Brady, and G.M. Mehrutra, "Twin Knudsen Cell Measurements of Aluminum Activities in TiAl Alloys," Electrochemical Society Extended Abst racts, 1 s8th Merting of the Electrochemical Society (Pernington, Nf: the Eilectrochemical Society, 1995).

14. M. Eckertet al., Ber. Bunsenges. Phys. Chem.. 100)(4)(1946), p. 418

P. 418 . Luthra, Ox. Met., 36 (5/6) (1991), p. 475

16. A. Rahmel and P.J. Spencer, Ox Met., $35(1 / 2)(1941)$, p

53. $\times$ L Li et al. Acta Metall Mater $40(11)(1992)$, 3149

18. M.X Zhang et al. Scripta Met. Mater., 27 (1992), p. 1361.

19 G.P. Kelkar and A.H. Carim, A. Am. Ceram. Soc, 78 (3)

19. G.P. Kelkar

(1995), p. 572.

Y. Y. Chen, D.]. Young and B. Gleeson, Materials Letters, 22 (1995), p. 125

21. W.E. Dowling, Jr. and W.T. Donlon, Scipta Met et Muter 27 (1992), p. 1663

22. R.W. Beye and R. Gronsky, Acta Met. et Mater 42 (1994) P. 1373

23. N. Zheng et al., Scripta Met. et Mater. 33 (1995) . . 47 24. Y.F. Cheng et al., Scripta Materialia, 34 (5) (1996), p. 707 25. F. Dettenwanger et al, "Development and Microstructure of the Al-Depleted Layer of Oxidized TiAl," Material and Corrosion, in press.

26. E.H. Copland, B. Gleeson, and D. Young, "Factors Affecting the Sub-Surface Formation of $\mathrm{T}_{\mathrm{x}} \mathrm{Al}, \mathrm{O}$, Phase During Oxidation of $\gamma$-TiAl Based Alloys," Pricedings of the 13 th International Corrosion Congress (Melbourne, Australia Int Corr. Council 1996)

27. N.S. Choudhury, H.C. Graham, and J W. Hinze, Proper ties of High Temperature Allows, ed Z.A. Fouroulis and F.S Pettit (Pennington, NJ: the Electrochemical Societv, 1976), p

osk.
28 . F. Dettenwanger et al., Mat. Res. Soc Sump. vol. 364 (1995), p. 981.

29. M Rakowski tet al, Scripta Met. et Mater. 33 (1995). 29. 1 .

30. N. Zheng et al. Ox. Met., 44 (5/6) (1995), p. 477

31. R.A. Perkins, K.T. Chiang, and G.H. Meier, Scripta Met 31. R.A. Perkins,

32. T.A. Wallace et al., Environmental Lffects on Adranced 32. T.A. Wallace et al., Environmental Lffects on Adranced
Materials, ed. R.H. Jones and R.E. Ricker (Warrendale, PA Materials, ed. R.H.

TMS, 1991), p. 79.
33. Y-W Kim, Mat. Res. Soc Symp. Proc., yol, 213 (Pittsburgh, 33. Y-W. Kim, Mat. Res.
PA: MRS, 1991), p. 777 .

34. D.W. McKee and S.C. Huang, Corrosion Saence, 33 (12) (1992), p. 1899

35. B.C. Kim, G.M. Kim, and C.J. Kim, Scripta Met et Mater. 33 (7) (1995), p. 1117.

36. J. Doychak, Intermetallic Compounds, ed. J.11. Westbrook and R.L. Fleischer (New York: John Wiley \& Sons L.td. 1994)

37. J.C. Schaeffer, C.M. Austin, and F. Kaempf, Gamma Tita mitm Aluminides, ed. Y.W. Kim, R. Wagner, and M. Yamaguch (Warrendale, PA: TMS, 1995), p. 71

38. M. Yoshihara, K. Miura, and Y-W. Kim, Gamma Titaninm Aluminides, ed. $Y-W$. Kim, R. Wagner, and $M$. Yamaguch (Warrendale, PA: TMS, 1995), p. 93

39. Y. Shida and H. Anada Ox Met. 45 (1/2) (1996) p 197 40. I.E. Locci et al., "Very Long Term Oxidation of Ti-48Al$2 \mathrm{Cr}-2 \mathrm{Nb}$ at $704^{\circ} \mathrm{C}$ in Air," submitted to Scripta Mater 41. W.J. Brindley, unpublished research

42. Y-W. Kim, JOM, 46 (7) (1994) p. 30. 43. S. Jain and J.R. Roessler, U.S. patent 5,296,056 (1994) 44. M. Schutze and M. Schmitz-Niederau, Camma Titanium Aluminides, ed. Y-W. Kim, R. Wagner, and M Yamaguchi (Warrendale, PA: TMS, 1995i, p. 83

45. J.L. Smialek et al, Mat. Res. Soc. Symp., vol. 364 (1995) p 1273 (1995)

46. G.H. Meier, "Research on Oxidation and Embrittle'men of Intermetallic Compounds in the U.S.," to be published in Materials and Corrosion.

47. W.J. Brindley et al., HITEMP Review-1994, NASA CP 10146 , vol. II, paper 44 (1994).

48. A.H Rosenberger, B.D. Worth, and S.J. Balsone, "Environmental Effects on the Fatigue Crack Growth of Gamm Titanium Aluminides, "to be published in the proceedings of
Sixth International Fatigue Congress, Berlin (May, 1996). 49. S.). Balsone et al., Mal. Sci. and Eng. A192/193 (1995) p 49. S.

50. S. Taniguchi, MRS Bulletin (October 1994), p. 31.

50. S. Taniguchi, MRS Bulletin (October 1994), p. 31 .
51. R. Streiff, lournal De Phusique IV, Colloque' $C 9$, vol. 3 51. R. Streiff

(1993), p. 17.

52. T.Shimizu, T. Iikubo, and S. Isobe, Mat Sci, and Eng, A153
(1992), p. 602. $5,116,690(1992)$ 54. W.J. Brindley, J.L. Smialek, and M.A Cedwill, HITLMP Revieu. 1992, NASA CP-10104, vol 11, paper 41 (1992).

55. D.W. Mckee, Mat. Res. Soc. Proc., 288 (1993), p. 953.

56. D.W. McKee and K.L. Luthra, Surface and Cuat Ings' Tech nology, 56 (1993), p. 109

57. R. Streiff and S. Poize, High Temperature Corrosion, ed R.A Rapp (Houston, TX: NACE, 1983), p. 591

58 H. Mabuchi, T. Asai, and Y. Nakayama, Siripta Met. 23 (1989), p. 685.

5y. J.LSmialek, M.A. Gedwilt, and P.K. Brindley, Scnpta Met et Mater, 24 (1990), p. 1291

60. M. Yoshihara, T. Suzuki, and R. Tanaka, ISI/ International. 60. M. Yoshihara, 1 Suz
31 (10) (1991), p. 1201.

61. J.L. Smialek, Corrosion Science, 35 (5-8) (1993), p. 1199

61. J.L. Smialek, Corroston Science, $35(5-8)(1493)$, p. 1199 .
62 C. Leyens, M. Peters, and W.A. Kaysser, "Influence of Intermetallic Ti-Al Coatings on the Creep Properties of Timetal 1100," submitted to 5 rripta Mater.

Timetal 1100," submitted to Smpta Mater. 63. T.C. Munroand B. Gleeson, "The Deposition of Atuminide' and Silicide Cuatungs on $\gamma$-TiAl Using the Halide-Activate

Pack Cementation Method," Met. Mat. Trans., in press.
64. R.P. Skowronski, l. Am. Ceram. So .,77 (4) (1994), p. 1098 64. R.P. Skowronski, I. Am. Ceram. So , 77 (4) (1994), p. 1098 .
65. W.C. Revelos and P.R Smith, Met. Tran A. 23A (1992), P. 567.

66. B. Cockeram and R.A. Rapp, Ox. Met., 45 (5/6) (1996). P 427.

67. W. J. Brindley and $P$.A. Bartolotta, unpublished research 68. R.A. Perkins and G.F. Meier, Procepdings of the Industry University Aduanced Materials Conference II, ed. F. Smith (Golden, $\mathrm{CO}$ : Advanced Materials Institute, 1989), p. 92. 69. I.C. Schaeffeet al., GE Aircraft Engines final report, Nava Air Development Center contract N62269-90-C-0287 (1993) 70. R.L. MoCarron et al., Titanium 1992, ed. F.1. Froes and 1 Caplan (Warrendale, PA: TMS, 1993), p. 1971.

71. M.P. Brady, J. Smialek, and I. Terepka, Scripta Me Mater. $32(10)$ (1995) p 1659

72. M.P. Brady J.L. Smialek, and D.L. Humphrey, Mal Kes

Soc. Symp, vol. 364 (1995), p. 1309.
73. J.L. Klansky, I.P. Nic, and D.E. Mikkola, J. Mater. Res., 9 (1994), p. 255 .

(1994), p. 255 .
74. T.J. Jewett and M. Dahms, Z. Metallkunde, 87 (1996).

74. T.J. Jewett and M. Dahms, Z. Metallkunde, 87 (1996).
75. M.P. Brady et al., "The Role of Cr in Promoting Protective 75. M.P. Brady et al., "The Role of Cr in Promoting Protective Alumina Scale Formation by $\Psi$-Based T1-Al-Cr Aloys: Part $1-$ Compatibility with Alumina and Oxid

76. Ten," to be published in Acta Met. 76. T.J. Jewett, B. Ahrens, and M. Dahms, "Phase Equilibria Involving the $\tau-\mathrm{L}_{2}$ and
Intermetallics, in press

Intermetallics, in press. 2619 .

78. M.P. Brady, J.L. Smialek, and W.J. Brindley, submitted to U.S. patent office (1996).

79. F.H. Hayes, I Phase Equilibria, 13 (1) (1992), p. 79.

\section{ABOUT THE AUTHORS}

Michael P. Brady earned his Ph.D. in mate rials science and engineering from the University of Florida in 1993. He is currently a National Research Council post-doctoral felIOw with NASA Lewis Research Center in Cleveland, Ohio. He is also a member of TMS.

William J. Brindley his Ph.D. in metallurgical engineering from Michigan Technological University in 1986. His is currently a research scientist with NASA Lewis Research Center in Cleveland, Ohio

James L. Smialek earned his Ph.D. in materials science from Case Western Reserve University in 1981. His is currently a senior research scientist with NASA Lewis Research Center in Cleveland, Ohio. He is also a member of TMS.

Ivan E. Locci earned his Ph.D. in materials science from Case Western Reserve University in 1986. He is currently a principal researcher at Case Western Reserve University in Cleveland, Ohio, and a research associate with NASA Lewis. He is also a member of TMS.

For more information, contact M.P. Brady, NASA Lewis Research Center, MS 106-1, 21000 Brook Park Road, Cleveland, Ohio 44135; (216) 4335504; tax (216) 433-5544; e-mail MichaelP. Brady lerc.nasa.gov. 